\title{
APLIKASI PENGELOLAAN BAHAN BAKU UNTUK EFISIENSI OPERASIONAL MENGGUNAKAN METODE ECONOMIC ORDER QUANTITY
}

\author{
Ruli Utami ${ }^{1}$, Shah Khadafi ${ }^{2}$ \\ ${ }^{1}$ Program Studi Sistem Informasi, Institut Teknologi Adhi Tama Surabaya \\ ${ }^{2}$ 1Program Studi Sistem Komputer, Institut Teknologi Adhi Tama Surabaya \\ Jl. Arief Rachman Hakim no 100 Surabaya \\ ruli.utami03@gmail.com,khadafi@itats.ac.id
}

\begin{abstract}
Abstrak
Pengelolaan bahan baku yang tepat akan memberikan kontribusi yang cukup besar dalam proses industri, sehingga ha ini dianggap menjadi hal penting bagi pelaku industri. Permasalahan bahan baku ini jugalah yang ada pada industri UKM kerupuk terasi yang berada di wilayah Kabupaten Lamongan khususnya di Kecamatan Turi, yaitu diantaranya adalah sering terhambatnya operasional industri dikarenakan tidak adanya sistem pengelolaan bahan baku, dikarenakan sering terjadi kekurangan bahan baku atau kelebihan stok bahan baku setiap bulannya. Sehingga peneliti berinisiatif untuk membuat aplikasi yang berfungsi untuk memberikan solusi pada masalah tersebut diatas. Adapun metode yang akan diimplementasikan pada aplikasi ini adalah metode Economic Order Quantity (EOQ), kesimpulan yang dapat ditarik pada penelitian yang telah dilakukan pada aplikasi pengelolaan bahan baku pembuat kerupuk dengan metode Economic Order Quantity (EOQ) adalah terbukti aplikasi ini dapat membantu efisiensi biaya produksi dalam hal pengelolaan bahan baku pembantu proses produksi. Dengan hasil perbandingan TIC dengan metode EOQ sebesar Rp. 311.572.670 setiap tahun untuk seluruh bahan baku, dan TIC dengan metode klasik (Tanpa EOQ) sebesar Rp. 338.071500. sehingga diperoleh angka efisiensi biaya operasional produksi melalui pengelolaan bahan baku adalah sebesar Rp. 26.498 .830 setiap tahunnya.
\end{abstract}

Kata Kunci : Pengelolaan Bahan Baku, Efisiensi Biaya, EOQ

\begin{abstract}
Proper raw material management will make a significant contribution to the industrial process, so this is considered to be important for industry players. The problem of this raw material also exists in the SME shrimp paste industry in the Lamongan Regency, especially in Turi Subdistrict, which is often hampered by industrial operations due to the absence of a raw material management system, because there is often a shortage of raw materials or excess raw material stock every month. So the researchers took the initiative to create an application that serves to provide solutions to the problems mentioned above. The method that will be implemented in this application is the Economic Order Quantity (EOQ) method, a conclusion that can be drawn from the research that has been done on the application of management of raw materials for cracker makers using the Economic Order Quantity (EOQ) method. in terms of managing the raw material for supporting the production process. With the results of the TIC comparison with the EOQ method of Rp. 311,572,670 annually for all raw materials, and TIC with the classical method (Without $E O Q)$ of Rp. 338.071500. so that the efficiency of production operational costs through the management of raw materials is obtained in the amount of Rp. 26,498,830 annually.
\end{abstract}

Keywords : Raw Material Management, Cost Efficiency, EOQ

\section{PENDAHULUAN}

Pengelolaan bahan baku menjadi salah satu kunci penting dalam menjalankan proses produksi industri, dengan pengelolaan yang tepat maka perencanaan produksi akan lebih efektif dan memperlancar proses penjualan hingga produk sampai ke tangan konsumen. Selain itu pengelolaan bahan baku juga memberikan dampak dan kontribusi yang cukup besar dalam mendefinisikan biaya produksi, yang nantinya akan berujung pada penentuan harga jual produk yang dihasilkan oleh sebuah proses industri [1]. Diperlukan suatu usaha yang serius untuk menangani dan membuat sebuah perencanaan bahan baku untuk mendukung kelancaran proses produksi sebuah perusahaan.

Dalam penelitian ini peneliti menggunakan industri rumah tangga atau UKM kerupuk terasi yang berada di wilayah Kabupaten Lamongan khususnya di Kecamatan Turi. Permasalahan yang ada pada 
industri ini diantaranya adalah sering terhambatnya operasional indstri dikarenakan tidak adanya sistem pengelolaan bahan baku, dimana sering terjadi kekurangan bahan baku atau kelebihan stok bahan baku setiap bulannya. Sehingga peneliti berinisiatif untuk membuat sebuah kajian ilmiah untuk memberikan solusi pada masalah tersebut diatas. Adapun metode yang akan diimplementasikan adalah metode Economic Order Quantity (EOQ). Metode ini dapat digunakan untuk menghitung persediaan ekonomis dengan mencari nilai dari jumlah pemesanan ekonomis setiap kali pesan, menghitung waktu antar pemesanan satu dengan pemesanan yang lain, menghitung jumlah atau frekuensi pemesanan dalam kurun waktu satu tahun, menghitung nilai safety stock sebelum melakukan pemesanan berikutnya, menghitung titik pemesanan kembali, serta menghitung nilai dari total biaya inventori.

\section{DASAR TEORI}

Pengelolaan bahan baku merupakan faktor yang penting karena dihitung sebagai investasi yang dapat dikonversikan sebagai nilai keuntungan yang dikelolah melalui penjualan suatu produk, sehingga stabilitas ketersediaan bahan baku harus dijaga sedemikian rupa untuk menjamin kontinuitas dan stabilitas proses penjualan [2]. Namun begitu, tidak semua kepentingan finansial dapat berjalan sejajar dengan kepentingan dalam penyediaan dan pengelolaan bahan baku untuk memenuhi kebutuhan produksi. Sehingga dibutuhkan satu angka penetapan yang dapat menentukan berapa jumlah optimal persediaan untuk mengatasi ketidaksinkronan kedua kepentingan tersebut [3]. Dalam operasionalnya, persediaan dapat dibagi menjadi beberapa bagian. Yaitu persediaan pengamanan (safety stock) dimana persediaan ini dimaksudkan untuk mengantisipasi ketidakpastian atau peningkatan produksi pada suatu produk, persediaan antisipasi (Anticipation Stock) dimana persediaan ini dimaksudkan untuk berjaga-jaga menghadapi naik turunnya permintaan yang sudah diperkirakan sebelumnya, dan persediaan dalam pengiriman (Transit Stock) dimana persediaan ini merupakan persediaan yang masih dalam proses pengiriman [4].

Terdapat beberapa faktor yang menentukan dalam menentukan kebijakan jumlah persediaan barang secara optimal yaitu biaya persediaan, besarnya tingkat permintaan suatu barang oleh pelanggan dalam satu periode atau satu tahun, lama waktu pengiriman mulai dari barang tersebut dipesan hingga barang tersebut diterima oleh pelanggan, perkiraan ada tidaknya penundaan pemenuhan permintaan barang oleh pelanggan, dan kemungkinan adanya potongan harga untuk pembelian dalam jumlah besar oleh pelanggan [5]. Agar perusahaan dapat memenuhi apa yang dibutuhkan oleh pelanggan, maka dilakukan usaha untuk memenuhi persediaan untuk kebutuhan proses produksi dengan melakukan pemesanan dan pembelian terhadap bahan baku yang dibutuhkan. Terdapat dua cara dalam pemesanan terhadap suatu barang yaitu order point system dimana pemesanan dilakukan jika persediaan telah mencapai satu titik tertentu, sedangkan cara kedua adalah order cycle system dimana pemesanan akan dilakukan dengan acuan interval waktu yang telah ditentukan sebelumnya [6]. Salah satu metode yang dapat diimplementasikan dalam studi kasus pengelolaan persediaan adalah Economic Order Quantity (EOQ), kunci dari metode ini adalah dengan cara memperkecil biaya pemesanan dan biaya penyimpanan pada masing-masing bahan baku [7]. Adapun grafik dari metode EOQ dapat dilihat pada gambar 1 berikut ini.

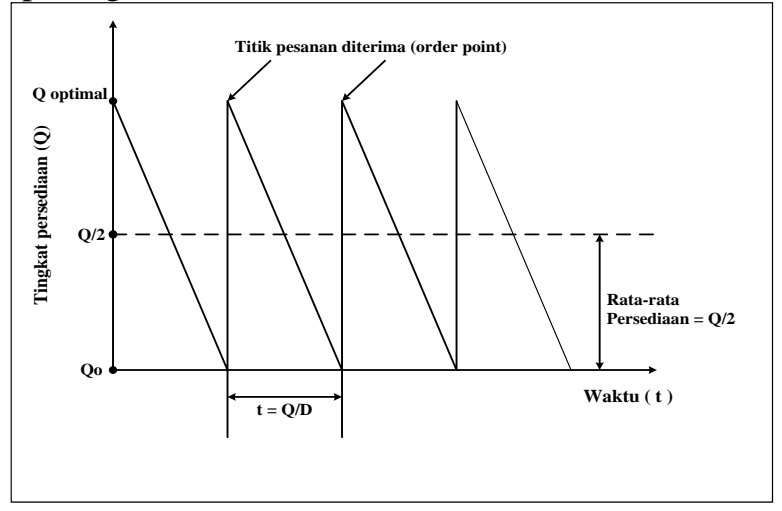

Gambar 1. Model EOQ [8]

EOQ dapat dihitung menggunakan persamaan-persamaan berikut ini, hal ini dilakukan untuk memperoleh nilai jumlah persediaan optimal guna efisiensi operasional perusahaan baik dalam proses produksi maupun penjualan barang kepada pelanggan [9]. Adapun batas toleransi yang diberikan oleh perusahaan adalah sebesar 5\% dengan nilai 1.6 [10]. 


$$
\begin{aligned}
\mathrm{Q} & =\sqrt{\frac{2 S D}{H}} \\
\mathrm{t} & =\frac{Q}{S} \\
\mathrm{~F} & =\frac{S}{Q} \\
\mathrm{SS} & =\mathrm{Sd} \times \mathrm{Z} \\
\mathrm{ROP} & =\mathrm{SS}+(\mathrm{L} \times \mathrm{S}) \\
\mathrm{TIC} & =\sqrt{2 D S H} \\
\text { TIC manual } & =(\text { Penggunaan Rata2 } \times \mathrm{H})+(\text { D.F })
\end{aligned}
$$
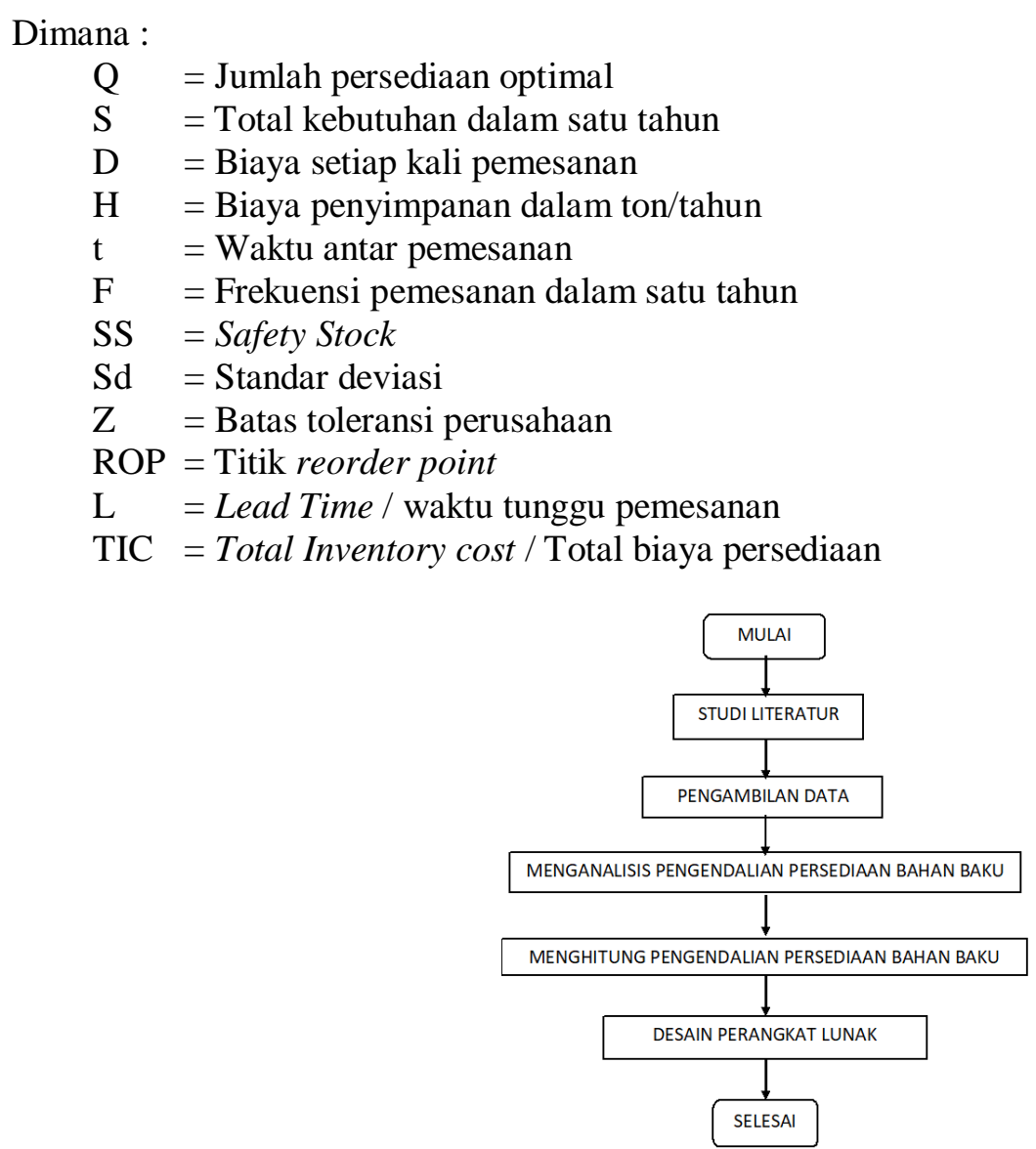

Gambar 2. Metode Penelitian dengan Menggunakan Metode EOQ

\section{METODOLOGI PENELITIAN}

Metode penelitian ini digunakan sebagai acuan dalam melaksanakan penelitian dengan metode EOQ pada UKM kerupuk terasi di Kabupaten Lamongan. Adapun langkah-langkahnya adalah dengan mencari studi literatur terkait proses bisnis pada UKM kerupuk terasi serta literatur pendukung secara ilmiah. Kemudian dilakukan pengambilan data yang selanjutnya akan di analisis untuk memperoleh poin-poin data yang dibutuhkan untuk penelitian. Jika data telah siap, baru akan dilakukan perhitungan untuk mencari nilai optimal untuk persediaan bahan baku kerupuk terasi. Dan langkah terakhir yang dilakukan adalah membuat 
desain untuk aplikasi yang nantinya dapat membantu mitra UKM dalam membuat pengelolaan persediaan bahan baku pembuat kerupuk terasi tersebut.

\section{HASIL DAN PEMBAHASAN}

\subsection{Pembahasan Data Penelitian}

Dari hasil pengambilan data, peroleh data perbandingan pemakaian masing-masing bahan baku (tabel 1), Biaya pemesanan bahan baku persatu kali pesan (tabel 2), biaya penyimpanan bahan baku perton/tahun (tabel 3) adalah sebagai berikut:

Tabel 1. Bahan Baku pembuat kerupuk terasi

\begin{tabular}{|l|r|r|r|}
\hline Bahan Baku & $\mathbf{8 ~ k g / p r o d u k s i ~}$ & $\mathbf{1 6} \mathbf{~ k g} /$ produksi & $\mathbf{2 4} \mathbf{~ k g} / \mathbf{p r o d u k s i}$ \\
\hline Tepung Terigu & 1.25 & 2.5 & 3.64 \\
\hline Tepung Tapioka & 5 & 10 & 15 \\
\hline Terasi & 0.5 & 1 & 1.5 \\
\hline Garam & 0.5 & 1 & 1.5 \\
\hline Gula Pasir & 0.35 & 0.7 & 1.05 \\
\hline Bawang Putih & 0.4 & 0.8 & 1.2 \\
\hline Kaldu & 0.1 & 0.2 & 0.3 \\
\hline
\end{tabular}

Tabel 2. Biaya pemesanan bahan baku kerupuk terasi

\begin{tabular}{|l|l|l|l|}
\hline Bahan Baku & B. Pemakaian Telepon & Biaya Pengiriman & Total Biaya Pemesanan \\
\hline Tepung Terigu & Rp. 15.000 & Rp. 20.000 & Rp. 35.000 \\
\hline Tepung Tapioka & Rp. 14.000 & Rp. 20.000 & Rp. 64.000 \\
\hline Terasi & Rp. 19.000 & Rp. 30.000 & Rp. 49.000 \\
\hline Garam & Rp. 10.000 & Rp. 10.000 & Rp. 20.000 \\
\hline Gula Pasir & Rp. 20.000 & Rp. 18.000 & Rp. 38.000 \\
\hline Bawang Putih & Rp. 23.000 & Rp. 26.000 & Rp. 49.000 \\
\hline Kaldu & Rp. 5.000 & Rp. 8.000 & Rp. 13.000 \\
\hline
\end{tabular}

Tabel 3. Biaya penyimpanan bahan baku kerupuk terasi

\begin{tabular}{|l|r|r|}
\hline \multicolumn{1}{|c|}{ Bahan Baku } & \multicolumn{1}{c|}{$\%$} & Biaya Penyimpanan \\
\hline Tepung Terigu & $15 \% /$ tahun & Rp. 65.000 \\
\hline Tepung Tapioka & $15 \% /$ tahun & Rp. 80.000 \\
\hline Terasi & $8 \% /$ tahun & Rp. 10.000 \\
\hline Garam & $5 \% /$ tahun & Rp. 2.500 \\
\hline Gula Pasir & $10 \% /$ tahun & Rp. 50.000 \\
\hline Bawang Putih & $18 \% /$ tahun & Rp. 55.000 \\
\hline Kaldu & $12 \% /$ tahun & Rp. 3.000 \\
\hline
\end{tabular}

Dengan menggunakan persamaan 1 diperoleh hasil perhitungan jumlah optimal pemesanan (Q) adalah seperti pada tabel 4 berikut, jumlah tersebut adalah jumlah setiap satu kali pemesanan.

Tabel 4. Hasil Perhitungan Jumlah Optimal Pesanan bahan baku kerupuk terasi

\begin{tabular}{|l|c|}
\hline Bahan Baku & Pesanan Ekonomis (Kg) \\
\hline Tepung Terigu & 27.84 \\
\hline Tepung Tapioka & 68.91 \\
\hline Terasi & 53.94 \\
\hline Garam & 68.92 \\
\hline Gula Pasir & 17.77 \\
\hline Bawang Putih & 20.57 \\
\hline Kaldu & 22.69 \\
\hline
\end{tabular}


Sedangkan waktu antar pemesanan akan dihitung menggunakan persamaan 2, dengan membagi jumlah optimal pesanan bahan baku tertentu dengan jumlah kebutuhan bahan baku tersebut selama satu tahun. Hasil dari perhitungan waktu antar pemesanan dapat dilihat pada tabel 5 berikut.

Tabel 5. Hasil Perhitungan Waktu Antar Pemesanan bahan baku kerupuk terasi

\begin{tabular}{|l|c|}
\hline Bahan Baku & Waktu Antar Pemesanan (Hari) \\
\hline Tepung Terigu & 14 \\
\hline Tepung Tapioka & 8 \\
\hline Terasi & 65 \\
\hline Garam & 82 \\
\hline Gula Pasir & 30 \\
\hline Bawang Putih & 31 \\
\hline Kaldu & 136 \\
\hline
\end{tabular}

Adapun frekuensi pemesanan dalam satu tahun adalah menggunakan persamaan 3, dengan hasil seperti pada tabel 6 berikut.

Tabel 6. Hasil Perhitungan Frekuensi Pemesanan bahan baku kerupuk terasi setiap tahun

\begin{tabular}{|l|r|}
\hline Bahan Baku & Frekuensi Pemesanan/Tahun \\
\hline Tepung Terigu & 26 \\
\hline Tepung Tapioka & 43 \\
\hline Terasi & 6 \\
\hline Garam & 4 \\
\hline Gula Pasir & 12 \\
\hline Bawang Putih & 12 \\
\hline Kaldu & 3 \\
\hline
\end{tabular}

Dengan mengetahui jumlah optimal pemesanan, waktu antar pemesanan dan frekuensi pemesanan setiap tahunnya, maka nilai berikutnya yang harus dicari adalah nilai safety stock dengan menggunakan persamaan 4 . Adapun toleransi standar deviasi yang digunakan adalah 5\% atau 1.6, hasil perhitungan safety stock dapat dilihat pada tabel 7 berikut.

Tabel 7. Hasil Perhitungan Safety Stock bahan baku kerupuk terasi setiap tahun

\begin{tabular}{|l|r|}
\hline Bahan Baku & Safety Stock $\mathbf{( K g )}$ \\
\hline Tepung Terigu & 4.42 \\
\hline Tepung Tapioka & 18.23 \\
\hline Terasi & 1.82 \\
\hline Garam & 1.82 \\
\hline Gula Pasir & 1.28 \\
\hline Bawang Putih & 1.46 \\
\hline Kaldu & 0.36 \\
\hline
\end{tabular}

Pada tabel 8 akan dilakukan perhitungan pada Reorder Point atau titik pemesanan kembali pada masing-masing bahan baku, sehingga kejadian kekosongan bahan baku tidak akan terjadi. Perhitungan ROP ini dilakukan dengan menggunakan persamaan 5.

Tabel 8. Hasil Perhitungan Reorder Point bahan baku kerupuk terasi setiap tahun

\begin{tabular}{|l|r|}
\hline Bahan Baku & Reorder Point $\mathbf{( K g )}$ \\
\hline Tepung Terigu & 16.59 \\
\hline Tepung Tapioka & 51.68 \\
\hline
\end{tabular}




\begin{tabular}{|l|r|}
\hline Terasi & 4.33 \\
\hline Garam & 4.33 \\
\hline Gula Pasir & 4.20 \\
\hline Bawang Putih & 4.80 \\
\hline Kaldu & 0.70 \\
\hline
\end{tabular}

Dengan persamaan 6 dan 7, ditentukan Total Inventory Cost (TIC) dengan menggunakan EOQ dan dengan metode klasik (tanpa menggunakan EOQ). Hasilnya dapat dilihat pada tabel 9. Dengan hasil ini dapat diketahui jika pelaku usaha kerupuk terasi dapat melakukan efisiensi biaya, karena terdapat selisih sebesar Rp. 26.498 .830 setiap tahunnya. Ini merupakan angka efisiensi biaya dengan penghematan untuk seluruh kebutuhan bahan baku pembuat kerupuk terasi.

Tabel 9. Hasil Perbandingan TIC dengan EOQ dan metode klasik bahan baku kerupuk terasi setiap tahun

\begin{tabular}{|l|r|r|r|}
\hline Bahan Baku & $\begin{array}{c}\text { TIC/tahun dengan } \\
\text { EOQ }(\mathbf{R p})\end{array}$ & $\begin{array}{c}\text { TIC/tahun tanpa } \\
\text { EOQ (Rp) }\end{array}$ & $\begin{array}{c}\text { Penghematan } \text { TIC } \\
\text { dengan EOQ/tahun (Rp) }\end{array}$ \\
\hline Tepung Terigu & 46.785 .050 & 51.825 .050 & 5.040 .000 \\
\hline Tepung Tapioka & 237.451 .200 & 246.667 .200 & 9.216 .000 \\
\hline Terasi & 2.968 .400 & 3.528 .000 & 559.600 \\
\hline Garam & 742.100 & 1.462 .100 & 720.000 \\
\hline Gula Pasir & 10.388 .000 & 17.122 .000 & 6.734 .000 \\
\hline Bawang Putih & 13.059 .750 & 16.130 .800 & 3.071 .050 \\
\hline Kaldu & 178.170 & 1.336 .350 & 1.158 .180 \\
\hline
\end{tabular}

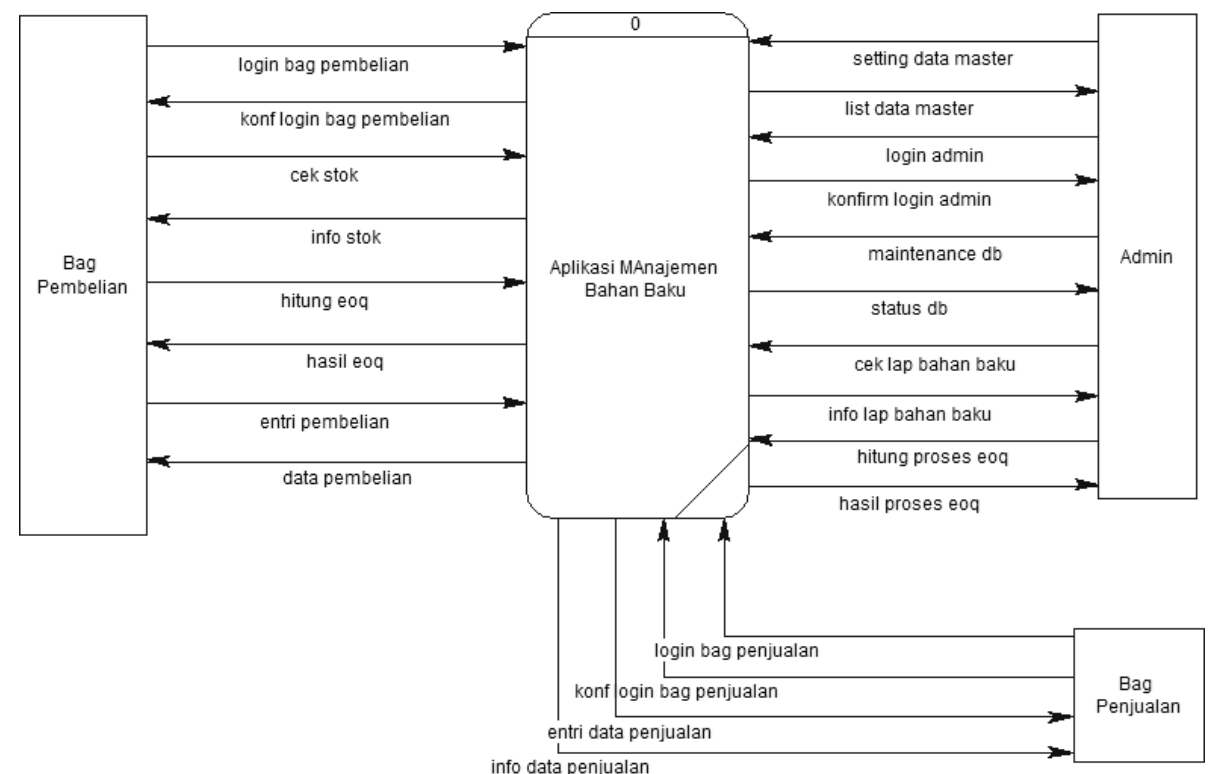

Gambar 3. Diagram Konteks Aplikasi Manajemen Bahan Baku Kerupuk Terasi

\subsection{Desain dan Hasil Sistem}

Perancangan sistem digambarkan melalui Data Flow Diagram (DFD). Diagram ini memberikan ilustrasi aktifitas yang ada pada sistem nantinya serta end-user secara fungsional yang dapat mengakses sistem EOQ ini. Sedangkan struktur dabatase dapat menggambarkan kebutuhan akan data pada sistem yang dapat membantu operasional sistem nantinya, adapun gambaran dari sistem dan struktur databasenya dapat dilihat pada gambar 3 dan 4. 


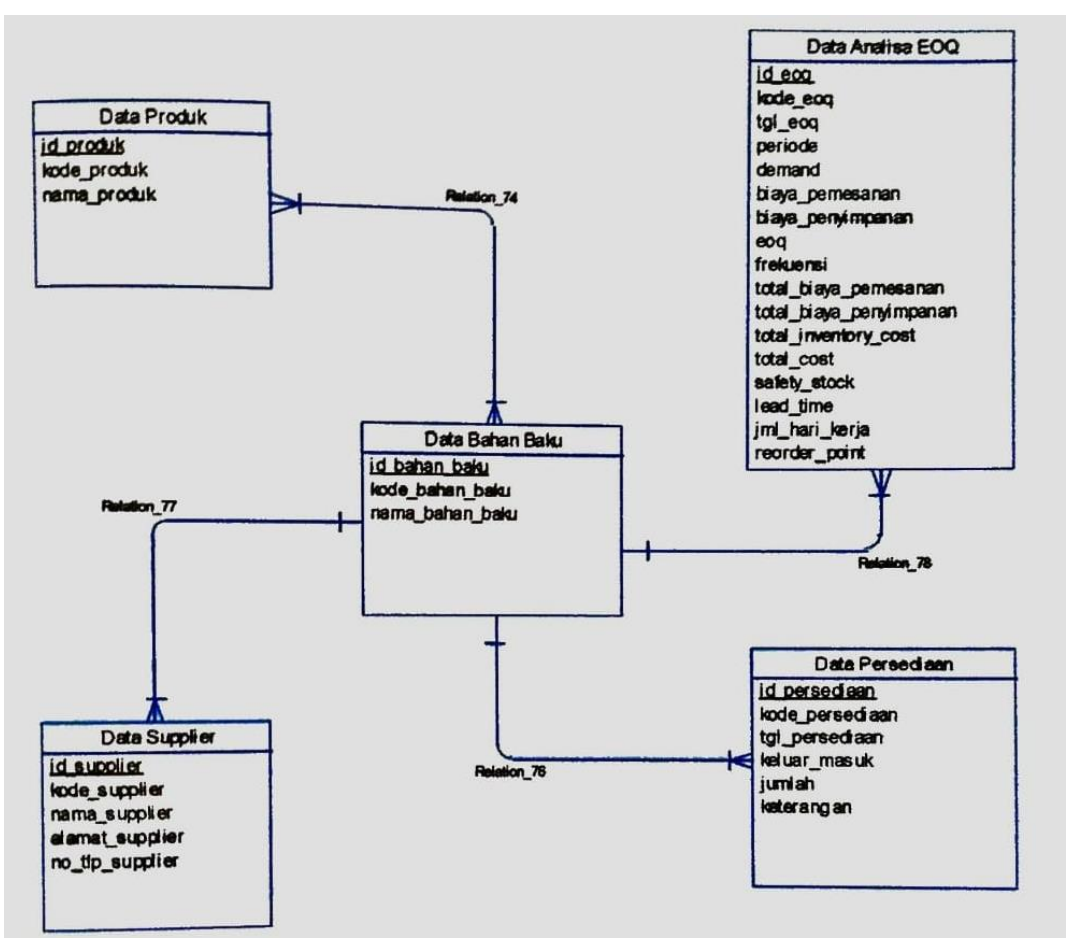

Gambar 4. Struktur Database untuk Aplikasi Manajemen Bahan Baku Kerupuk Terasi

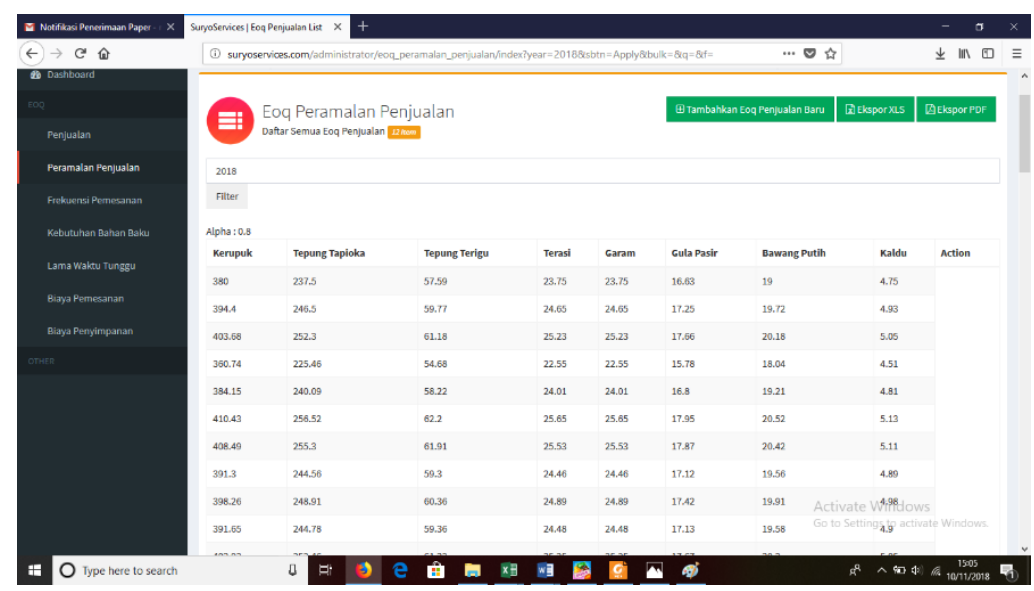

Gambar 5. Aplikasi Pengelolaan Bahan Baku Kerupuk Terasi

\section{KESIMPULAN}

Kesimpulan yang dapat ditarik pada penelitian yang telah dilakukan pada aplikasi pengelolaan bahan baku pembuat kerupuk dengan metode Economic Order Quantity (EOQ) adalah terbukti aplikasi ini dapat membantu efisiensi biaya produksi dalam hal pengelolaan bahan baku pembantu proses produksi. Dengan hasil perbandingan TIC dengan metode EOQ sebesar Rp. 311.572.670 setiap tahun untuk seluruh bahan baku, dan TIC dengan metode klasik (Tanpa EOQ) sebesar Rp. 338.071500. sehingga diperoleh angka efisiensi biaya operasional produksi melalui pengelolaan bahan baku adalah sebesar Rp. 26.498.830 setiap tahunnya.

\section{Ucapan terima Kasih}

Peneliti berterima kasih pada Direktur Riset dan Pengabdian kepada Masyarakat (DRPM) Ristekdikti melalui DIPA 2017 atas segala dukungan material dan nonmaterial. 


\section{DAFTAR PUSTAKA}

[1] N. K. D. A. Jayanti, Prapitasari, "Penerapan Metode EOQ (Economic Order Quantity) Pada Peramalan Stok Barang”, Konferensi Nasional Sistem \& Informatika, Hal. 648-653, Oktober 2015.

[2] A. F. Amrilla, Zahroh, Goretti Maria, "Analisis Metode Economic Order Quantity (EOQ) Sebagai Dasar Pegendalian Persediaan Bahan Baku Pembantu (Studi Pada PG. Ngadirejo Kediri - PT. Perkebunan Nusantara X)", Jurnal Administrasi Bisnis, Vol.33 No.1, Hal 35-42, 2016.

[3] M. H. Maharani, Kamal, "Perbandingan Sistem Economic Order Quantity dan Just in Time Pada Pengendalian Persediaan Bahan Baku ", Diponegoro Journal of Management, Vol 4 No 2, Hal 1$15,2015$.

[4] M. C. Teurah, "Analisis Pengendalian Persdiaan Bahan Baku Ikan Tuna pada CV. Golden KK", Jurnal Emba, Vol.2 No. 4, Desember 2014.

[5] R. Wahyudi, "Analisis Pengendalian Barang Berdasarkan Metode EOQ di Toko Era Baru Samarinda", eJournal Ilmu Administrasi Bisnis, Vol.2 No. 1, 2015.

[6] J. Puspika, Anita, "Inventory Control dan Perencanaan Persediaan Bahan Baku Produksi Roti Pada Pabrik Roti Bobo Pekanbaru", Jurnal Ekonomi, Vol 21 No 3, Hal 1-15, 2013.

[7] K. Rakesh, "Economic Order Quantity (EOQ) Model", Global Journal of Finance and Economic Management, Vol 5 No 1. Pp 1-5, 2016.

[8] N. L. P. Hariastuti, "Analisis Pengendalian Persediaan Bahan Baku Dengan Metode EOQ Guna Mencapai Tingkat Persediaan Optimal”, Jurnal IPTEK, Vol.12 No. 1, 2009.

[9] Syamsuddin, Lukman "Manajemen Keuangan Perusahaan”, Rajawali Pers, 2011.

[10] M. Simbar, Katiandhago, "Analisis Pengendalian Persediaan Bahan Baku Kayu Cempaka Pada Industri Mebel Dengan Menggunakan Metode EOQ”, Jurnal Cocos Fakultas Pertanian Universitas Sam Ratulangi, Vol 5 no 3, 2014. 